\title{
Women with cardiopathy in the context of reproductive planning: contributions of phenomenological hermeneutics
}

\author{
Mulheres com cardiopatia no contexto do planejamento reprodutivo: contribuições da hermenêutica \\ fenomenológica \\ Mujeres con cardiopatia en el contexto del planeamiento reproductivo: contribuciones de la hermenéutica \\ fenomenológica
}

Thaís Vasconselos Amorim ${ }^{1}$ (iD Ívis Emília de Oliveira Souza² Anna Maria de Oliveira Salimena ${ }^{1}(\mathbb{D})$

Ana Beatriz Azevedo Queiroz ${ }^{2}$ (D) Elayne Arantes Elias ${ }^{2}$

${ }^{1}$ Universidade Federal de Juiz de Fora. Juiz de Fora, MG, Brasil.

${ }^{2}$ Universidade Federal do Rio de Janeiro, Escola de Enfermagem Anna Nery. Rio de Janeiro, RJ, Brasil.
Corresponding author:

Thaís Vasconselos Amorim.

E-mail:thaisamorim80@gmail.com

Submitted on 06/05/2019.

Accepted on 09/12/2019.

DOI: 10.1590/2177-9465-EAN-2019-0164

\begin{abstract}
Objective: To analyze the existential movement of women with heart diseases in the context of Reproductive Planning Method: Qualitative with Heideggerian phenomenological approach. Seventeen participants with heart disease and with recent experience of pregnancy at a reference institution for maternal risk participated in the study, through the phenomenological interview. Results: Two units of meanings emerged in the hermeneutical analysis: To be more attentive and concerned with the treatment because the problem remains the same; Expressing that they don't want to get pregnant anymore because they've reached the limit and to seek planning in doing the tubal ligation. Conclusion and implications for practice: The unveiling of the existential movement made it possible to understand that, although the participants felt secure with the institutional follow-up of high-risk pregnancies, this proved to be insufficient with regard to Reproductive Planning. It stands out the necessary consideration by nurses and other health professionals that this planning is an important set of actions to identify and modify risks in women with heart diseases in the perspective of better perinatal outcomes. It is necessary to advance in the comprehension of the subjective aspects of the woman and the couple through the dialogue, besides the permanent education work of the whole team.
\end{abstract}

Keywords: Heart Diseases; Family Planning; Qualitative Research; Nursing Care; Women's Health.

\section{RESUMO}

Objetivo: Analisar o movimento existencial da mulher com cardiopatia no contexto do Planejamento Reprodutivo. Método: Qualitativo com abordagem fenomenológica Heideggeriana. Foram participantes 17 mulheres cardiopatas com experiência recente de gravidez em instituição referência para risco materno, por meio da entrevista fenomenológica. Resultados: Emergiram na análise hermenêutica duas unidades de significados: Ficarem mais atentas e preocupadas com o expressarem tratamento porque o problema continua o mesmo; Expressarem não querer mais engravidar porque chegaram no limite e buscarem o planejamento para fazer laqueadura. Conclusão e implicações para a prática: $O$ desvelamento do movimento existencial permitiu compreender que, embora as participantes se sentissem seguras com o acompanhamento institucional da gravidez de alto risco, este se mostrou insuficiente no tocante ao Planejamento Reprodutivo. Aponta-se a necessária consideração por parte de enfermeiras e demais profissionais de saúde de que esse planejamento é um importante conjunto de ações para identificar e modificar riscos em mulheres com cardiopatia na perspectiva de melhores resultados perinatais. Deve-se avançar na abrangência dos aspectos subjetivos da mulher e do casal por meio do diálogo, além do trabalho de educação permanente de toda a equipe.

Palavras-chave: Cardiopatias; Planejamento Familiar; Pesquisa Qualitativa; Cuidados de Enfermagem; Saúde da Mulher.

\section{RESUMEN}

Objetivo: Analizar el movimiento existencial de La mujer con cardiopatía en el contexto del Planeamiento Reproductivo. Método: Cualitativo con enfoque fenomenológico Heideggeriano. Fueron participantes 17 mujeres cardiópatas con experiencia reciente de embarazo en institución referencia para riesgo materno, a través de la entrevista fenomenológica. Resultados: emergieron las unidades de significados: Estar más atentas y preocupadas con el tratamiento porque el problema continúa el mismo; Expresar no querer más embarazarse porque llegaron al límite y buscar planeamiento para hacer ligadura. Conclusión e implicaciones para la práctica: El desvelamiento del movimiento existencial permitió comprender que, aunque las participantes se sintieran seguras con el acompañamiento institucional del embarazo de alto riesgo, éste se mostró insuficiente para el planeamiento reproductivo. Es necesaria la consideración por parte de enfermeras y demás profesionales de salud de que el planeamiento es un importante conjunto de acciones para identificar y modificar riesgos en mujeres con cardiopatía en la perspectiva de mejores resultados perinatales. Se debe avanzar en el alcance de los aspectos subjetivos de la mujer y de la pareja a través del diálogo, además del trabajo de educación permanente de todo el equipo.

Palabras clave: Cardiopatías; Planificación Familiar; Investigación Cualitativa; Atención de Enfermería; Salud de la Mujer. 


\section{INTRODUCTION}

Morbidities directly related to pregnancy such as hypertension, diabetes, pre-eclampsia, eclampsia and premature birth increase the risk of developing heart disease, although scores do not yet include this association. ${ }^{1}$ Heart disease has been pointed as the main cause of indirect obstetric maternal death worldwide and, in Brazil, also associated with increased near miss events. ${ }^{2-3}$

The medical diagnosis of heart disease occurs previously the pregnancy classified as high risk due to the increased chance of maternal and fetal complications. The presence of predictors such as cyanosis, functional class greater than II, ventricular ejection fraction less than $40 \%$ and previous cardiovascular disorders, increase the additional risk of heart events in the gestational period by $25 \%$ and $75 \%$ this same risk if identified two or more factors. ${ }^{4 \cdot 5}$

Despite these potential risk, many women with heart disease wish to become pregnant, and this should be considered in the reproductive planning assistance, which comprehends expanded and reproductive rights actions in the plan of attention to the integrality and equity principles, favoring the autonomy of all women and men in child programming from the beginning and throughout the sexual life, by means of health promotion, prevention, health education, provision of information, fertility regulation methods and techniques. ${ }^{6}$

In this sense, the importance of planning faced the risk situation for heart disease, in a way that women can have access to information and are in the best possible physical condition before becoming pregnant. For such, as attributes to be developed by nurses and other health team members, are the inclusion of partners through communication, flexibility and individualization. ${ }^{7-9}$

However, commonly, the planning that should permeate all persons is constituted in a punctual way, during the prenatal of the ongoing pregnancy. Pregnancy is configured as the period in that experiences and livingness accumulated and denoted by the followup of the pregnant puerperal cycle with important physiological changes, possibilities of hospitalizations arising from cardiovascular complications, carrying out of procedures, examinations and consultations, which contributes to a lesser understanding of orientations regarding future pregnancies. One also knows that such understanding constitutes adherence to contraceptive proposals insofar as the prenatal follow-up is effective, when considering the biopsychosocial spiritual aspects. ${ }^{8,10}$

Although women with heart diseases are monitored by multidisciplinary teams in the health care network, during the medical and nursing consultations, sometimes, questions related to reproductive planning are not addressed and when they do, professionals use directive, imperative and little dialogic discourses ${ }^{10}$, with minimal possibilities of women's expression in their singularity.
From the understanding that heart disease itself threats the women, one questioned how is for the woman to gestate with heart disease. This is because however advanced the technical aspects of management of clinical situations, those of subjective nature remain veiled, obscured and little or not always prioritized by the care methodologies in the health field. ${ }^{11}$

Thus, oriented by the need for individualization of care and active listening that professionals should practice with regard to Reproductive Planning, a greater nurses' participation in the multidisciplinary team of obstetric care in front of the gestational risk and, in face of the heart disease magnitude in the maternal morbidity and mortality, it was aimed to analyze the existential movement of women with heart disease in the context of the Reproductive Planning.

\section{METHOD}

Research of a qualitative nature, descriptive with phenomenological approach in Martin Heidegger. The choice of this referential was due to the understanding that phenomenology makes possible in view of the phenomena that involve the human being in its singularity. ${ }^{12}$

Accordingly, we sought access to possible participants in the research scenario represented by a reference institution for high maternal risk in the Southeast Region, Brazil. At the outpatient level, pregnant women with risk classification by primary care are accompanied in this scenario, by a multidisciplinary team composed of doctors and nurses during the pregnant puerperal cycle. It should be noted that the researcher had no link with the research scenario.

The field stage was carried out between July and December 2014. The prenatal sector allowed access to the prenatal consultation agenda records related to women with heart disease who had lived or were living the high-risk pregnancy at the referred institution. For the lived experience, the date of birth was set between July 2013 and July 2014; and for the experience in course, probable dates of birth until the end of the data collection period.

The inclusion criteria were women with heart disease of any type who were experiencing or had experienced the pregnancy at some moment in their lives; women who carried out the prenatal follow-up at the outpatient clinic of the referred scenario or who were admitted to the institution during the pregnant puerperal cycle. And, as exclusion criteria: women with mental disorders and under 18 years ${ }^{13}$.

A spreadsheet constructed from the access to the records of 45 women of the prenatal agenda favored the making of telephone contact with the possible participants to explain the research objectives and implement the invitation. Of this total, 23 women complied and 17 attended on the days and times previously scheduled for the interview. 
The data collection technique was open interview, carried out in accordance with the woman's preference, in the offices and other environments of the own research scenario or at home, with an average duration of 32 minutes. From the intersubjectivity moment mediated by empathy, it was possible to provide the phenomenological meeting with openness for the free expression of the deponents.

The speeches were recorded in digital media favoring the reliable transcription of their verbal expressions. In order to preserve the participants' identity and to ensure the anonymity, privacy and confidentiality of the observed or revealed information, an alphanumerical code represented by the letter "P" followed by the corresponding and sequential number of the interviews (P1, P2, P3...P17). ${ }^{11}$

The movement of analysis concomitant to the field stage began with listening and transcription of the recordings followed by reading of the same, in order to distinguish essential structures from occasional, aiming of having the investigation as a guide for the first, that are reveling of the phenomenal dimension.

The data saturation criteria came from the in-depth analysis processes of the empirical material and the absence of new meanings for discussion of the phenomenon under study. 14-15 Thus, for the conclusion of the field stage, in view of the phenomenal emergence driven by the sufficient expression of essential structures, we considered 17 interviews, proving unnecessary to look for other possible participants who were living the pregnancy.

Thus, the unit of meanings was constituted as a posteriori category. The methodological referential adopted guides the researcher to go through two different stages, being the first called vague and median understanding. This is possible by the understanding of the facts or ontic sphere dimensions, indicating initially the direction of the investigation ${ }^{12}$ when revealing how the woman understood her lived/experience in prenatal care in the face of the Reproductive Planning.

The second methodical moment is called hermeneutics, which announced the phenomena dimension or ontological sphere that reveals the existential movement through the interpretation of the senses. ${ }^{12}$ Thus, the discussion focused on the unveiling of the senses through the own concepts of the referential - the hermeneutics of the being-there-woman-withheart disease- supporting on research results that corroborate the problem under study.

The analytical movement allowed the construction of two Units of Meanings: Be more attentive and concerned about the treatment because the problem remains the same and; Express that they do no longer want to become pregnant because they have reached the limit and seek planning to do tubal ligation.

Regarding research with human beings, the precepts of Resolution No. 466/2012 were followed, and the field stage conduced in an ethical way with approval and deferment by the Research Ethics Committees, through the opinions number: 1.103.165 and 1.139.507.

\section{RESULTS}

The seventeen participants were aged between 19 and 40 years. The average of pregnancies was 2.4 with 1.7 births and 1.2 abortions (among six of 17 participants). The interpregnancy interval has presented an average time of five years. Relating to the number of children before the last pregnancy, $41 \%$ of women had a child, $23 \%$ had two and $6 \%$ had three children. Thirteen women said they had not planned their pregnancy and four wanted to become pregnant.

The clinical diagnoses were related to the rheumatic cardiomyopathy (6) of which three respectively concomitant with murmur, mitral regurgitation and mitral valve injury; ischemic heart disease (2), of which one accompanied by arrhythmia; congenital heart disease (1); arrhythmia (2) one of them being diagnosed with Wolff Parkinson-White Syndrome; mitral regurgitation (4); dilated cardiomyopathy (2) one of them accompanied by peripartum heart disease. Approximately nine women were hospitalized for an average of 23 days during the pregnant-puerperal cycle due to complications resultant from heart disease. ${ }^{13}$

In Becoming more attentive and concerned about the treatment because the problem remains the same, the participants described the care, the worries and feelings during pregnancy and after the birth of the baby, reinforcing the concern about the disease.

[...] now I have more willingness to treat myself [...] being always right doing my treatment $(P 1)$.

I already started taking the Marevan straight and everything is normal, the crisis I was in, I'm fine [...] (P4).

Now I worry a lot more, type what I eat, then I'm more light, first, due to the problem, because my cardiologist is always saying: always aware of your weight, the fact that you don't smoke, don't drink has helped a lot (P5).

[...] it was a good experience, even because I avoided somethings in pregnancy I avoid now and there was a good result relating to feeding. The pregnancy has passed, but the health, the problem remains the same that is the heart, high pressure (P10).

With regard to the care of me, I think I haven't stopped to think about this part [...] You begin to care more of you because of the persons who are around you, who take care of you and end up taking care of you too. I was very relaxed even with myself $(P 13)$.

Otherwise, in Expressing that they no longer wanted to get pregnant because they reached the limit, the women explained that they would not get pregnant again because of their health and other questions, so they searched for planning through the tubal ligation.

Then now in G. 's pregnancy, I started to do the planning, they gave me the papers. I addition to my heart problem, financially, I cannot afford to have another child (P3). 
[...] I fought a lot to have my child, but today I tell you, I would not get pregnant again, because so for my health I'm afraid to come the same came (P9).

I think I reached my limit, more a hospitalization I think that I could not stand, stay away from my children, hospitalized, alone, and feeling sick. So much so, I'm planning, if I had health for that, I'd like to have one more, but my health is not good (P12).

I would very much like to do the tubal ligation I did the family planning. They were even explaining that you put the IUD and then you get in a queue to do the tubal ligation, because sometimes they like to have that time to see if your baby will succeed, you have no problem wanting another child, but in my case, I do not want, I'm not healthy to have another baby even if the fatality happened. (P13).

I realized the family planning in order to do the tubal ligation and in the last day of my consultation in the prenatal the doctor (female) the doctor (female) came telling that my physician who will sign my tubal ligation, did not sign it because I had any in life [...] It was another thud for me [...]I came from far to do the family planning counting on it (P14).

\section{DISCUSSION}

The hermeneutics as an interpretative comprehension of the women with heart disease in the context of the Reproductive Planning made it possible through the ways of being that the participants meant in their speeches. The meanings pointed to an unveiling of the existential movement of the decadence, whose mention does not intent to make moral and value judgements. Decadence $^{12}$ reveals a way of life characteristic of the human being in its daily when moving existentially absorbed and guided by the others, showing itself stuck to the discourses and dictates of others, professionals, institutional and of public policy.

In a similar way, by understanding lived experiences and perceptions of women with higher risk pregnancy, one study found that the women had difficulty to understand from themselves the health problems that motivated the gestational risk classification. Despite this, they recognized the institution specialized in the prenatal follow-up as appropriated for the healthcare they needed in the face of the valorization of procedures provided in the service protocols. ${ }^{16}$

In rethinking and valuing its life, the being-there-woman admitted even having more attention to herself and taking more physical and emotional care of herself during and after the pregnancy. However, she shows herself as decadent in admitting that this care occurs by the heart disease and seeks the planning that the health system offers in protocol time and mode. The protagonism that should have been of the woman was transferred to the professional in the heteronomy that characterizes the subject-object relationship. Although the extension of the Reproductive Planning concept has already been proposed, the Family Planning is still in force in a reductionist, sometimes prejudiced and discriminatory perspective ${ }^{17}$.
Thereby the strategies offered by the tertiary care under the Family Planning label are not sufficient enough, but, especially the possibility of care in a subject-subject relationship and in a network of references and against references ${ }^{18}$ in addition to the planning in a single locus, since even though this is being followed by the woman in the perspective of avoiding the pregnancy, the pregnancy can occur at any time.

This is because despite the fact that the directive counseling is appropriate when there is a risk of maternal and fetal death, women present conceptions about the risks different from the conceptions of the professionals who accompany them, besides their reproductive choices are more strongly based on subjective and socioculturally influenced aspects. It is further considered that the decision making regarding contraception may be misleading due to lack of knowledge of the own contraceptive methods risks, reinforcing the need for guidance and health education. . $^{5,8}$

Significant number of pregnancies confirmed as intended were not planned sand result from ambiguity and fatalism. It was verified that in women who stated they had no desire to become pregnant and others who did not want a pregnancy in the next year of their lives, more than half were at risk of unintended pregnancy. ${ }^{8}$ In Brazil, data from the National Survey on Childbirth and Birth indicate that $56 \%$ of women had not planned the pregnancy and of the total of interviewed, $25 \%$ had the pregnancy classified as at risk. ${ }^{19}$

In this prerogative, one questions the woman's path in the care lines considering the interpregnancy interval of the participants in average of five years, in addition to the previous knowledge of heart disease in all pregnancies. When analyzing health care itineraries of women with a history of hypertensive syndromes during pregnancy, it was evidenced that in the before and after pregnancy, the women and health professionals sometimes, disregarded the reproductive risk, allowing the inappropriate use of contraceptive methods and implicating acute chronic conditions. ${ }^{20}$

In our research, $40 \%$ of women had a previous diagnosis of rheumatic heart disease. One knows that pregnant women with rheumatic lesions can have cardiovascular complications and worsening up to two levels in the functional class. In parallel, when assessing the impact of the heart disease during pregnancy, it was found that most complications that increase the maternal morbidity and mortality occur in women known to be heart disease bearers, reinforcing the importance of the Reproductive Planning..$^{3-4}$

Reproductive Planning is often confused with Family Planning and Preconception counseling. The later are tools that make up the former, which should start at the beginning of the sexual life, especially for women with heart disease. It, therefore, differs from traditional punctual care practices prior to the decision to become pregnant and during prenatal care. ${ }^{6}$ 
Family planning is present in most levels of health care, especially in the Primary Health Care by means of educational groups that encourage the use of contraceptive methods. Despite being a strategy of opening for the Reproductive Planning, it imposes itself vertically, with isolated and fragmented actions that disfavor the autonomy of men and women in relation to its sexual and reproductive life. ${ }^{16}$

The participants in this study concern the Family Planning as a way of accessing to the contraception in the modalities of tubal ligation and intrauterine device implantation (IDI). In women with high-risk heart disease, the tubal ligation is legally recommended, which should be analyzed carefully by the couple and supported by the multidisciplinary team, and is prohibited the carrying out of the procedure at the moment of the abortion, childbirth and puerperium up to 42 days after the birth. ${ }^{21}$

Among the reversible methods, the oral hormonal contraceptive for women with medium and low risk heart disease stand out, and their risks are associated with the greater number of venous thromboembolism. Intrauterine devices are an option for those who cannot use the oral contraceptive although the IUD is contra-indicated in women with history or at risk of bacterial endocarditis, cardiac valve prosthesis, mitral and aortic insufficiency, among others. ${ }^{21}$

In the context of the Primary Health Care, the Reproductive Planning is an important action for the health of women exposed to gestational risk, and should be able to provide not only orientations, but also the presentation of different modalities of anticonception to enable the women's choice as well as the couple, by respecting their decisions and orienting about the advantages and disadvantages of each method ${ }^{22-23}$, which was not observed through the participants' speeches.

A well-directed contraception and focused on the couple's needs contributes to the maternal and fetal morbidity and mortality prevention. However, it should be noted that the limitation of the health system in the quantitative of material and qualitative of professional to meet regularly the demands of the Reproductive Planning. The insufficient distribution of the methods and the unavailability of gynecological care undermine the continuity of care, in addition to the courses for pregnant women and groups of sexual and reproductive rights are presented in an isolated way and unable to offer the necessary support. ${ }^{22}$

In parallel, despite the public policies calling for the need for the men's inclusion in discussions that involve both the Reproductive and the Family Planning, the care practice is limited and focused only in the care of women, not considering the partner's inclusion even before the reproductive risk. The lack of programmatic investment in the organizational structure of services faced with the social demand to which the man has to respond, as well as the quantitative and qualitative insufficiency of persons for the carrying out of programs stands out as the barriers and unsuccessful factors. Moreover, a broad discussion should be done with the society in a way to evoke the political accountability of the Brazilian State. ${ }^{24}$
In view of the need for the specific contraception in accordance with the classification of the heart functional capacity, it stresses the importance of the preconception multidisciplinary counseling, besides ensuring access to other methods and the active search for dispersed women of and in the health system. Such dispersion can be attached to the chronology established for follow-up the baby for two years after the birth. ${ }^{7}$

It is strengthened that this woman's limited stay and limited to the child ratifies the decadence as way of life in which women with heart disease of childbearing age feel themselves to be assured only during the pregnancy, birth and puerperium, following a biomedical logic that obscures possibilities of care from the being-there-women at risk situation.

On the one hand the dismemberment of programmatic areas facilitates macro political management, on the other hand it greatly fragments health care making the intra and inter institutional difficult in the face of social demand. At one time, the attention to this woman's health focuses on obstetrical issues, at another, on early detection of the cervical and breast cancer, and at other moments, on chronic diseases. Little has been done to develop systemic integration responses among the noncommunicable chronic diseases (NCCD) programs and Women's Health programmatic area. ${ }^{2}$

Regarding the gestational risk for heart disease, before planning the pregnancy, there should be a good communication between the couple and the multidisciplinary team with expertise in the management of cardiovascular disease and pregnancy in this condition. ${ }^{10}$ Thirteen of seventeen participants in our study stated they had not planned the pregnancy, while four women despite reporting that they wanted to become pregnant, were not undergoing preconception care follow-up. It can also understand that the care practices, in the context of the Reproductive Planning must be carried out in an extensive and continuous way to all people who wish to program reproductive life. ${ }^{17,23}$

One understands that this follow-up should be routinely provided to all women of reproductive age, ensuring great specificity to those with CDNC. In this context, 30 to $90 \%$ of women present at least one indication that may benefit from an appropriate intervention previously to conception. However, only 30 to $50 \%$ of the pregnancies occur with a preconception care plan. However, in addition to consultation with different professionals and among them, the nurse, the counseling is not only relevant as immediate effect, but as a long-term benefit that will influence the planned baby up to its adult age, when will be also attentive for the adequate pregnancy planning. ${ }^{25}$

The inadequate educational work due to poorly provided guidelines, the belief from professionals that the women seek for themselves the pre-conceptual care, the limited time for consultations and the complexity of the discussion about care in relation to the clinical priorities ${ }^{25}$ are barriers for an adequate integral care to the reproductive health of women with chronic diseases. 
From this, we can infer that in addition to the multidisciplinary team who assists the pregnant, it is necessary to have a linearity of concepts around the humanistic and humanization principles, valorizing the woman's and couple's discourse through an attentive listening, which will enable an authentic care by the opening of the being, centered in its needs and in articulation with the ontic and ontological dimensions.

The results evidence relevant aspects to be considered in the clinical practice of health professionals who work both in the Woman's Health area and in the health care on women with chronic-degenerative diseases. The study limitation results from the investigation in a single and reference scenario in high-risk pregnancy. However, It is agreed that in the epidemiological context, the development was conducted according to the adopted theoretical referential.

\section{CONCLUSIONS AND IMPLICATIONS FOR PRACTICE}

The unveiling of the decadence as an existential movement of the being-there-woman-with-heart disease in the Reproductive Planning context, allowed us to understand that although the participants felt safe with the institutional follow-up of highrisk pregnancies, this proved to be insufficient regarding the reproductive planning, and still revealed weaknesses of the Health System as a reproductive health care network for women at risk.

One points out the necessary consideration by the health professionals that the reproductive planning is an important set of actions to identify and modify risks in women with heart disease from the perspective of obtaining better perinatal results. However, it is necessary to advance in the comprehension of the subjective aspects of the women and the couple by means of the dialogue between them and the health professionals, beyond the permanent education work of all team.

In this sense, the Reproductive Planning at primary level occupies a prominent place for the population health promotion, and should seek interface to the other healthcare levels to differentiate the displacement within the network from the displacement on network, contemplated by the meanings of link, welcoming, accountability and integrated health practices.

The disposition of greater proximity between the beingwho-cares of and the being-of whom- is cared of shows as inherent to the SUS principles and pertinent to the Health Policies of the Women. This will require broadening the look around the care in the context of the Reproductive Planning that calls for plural considerations arising from the women's and the couple's world view in their social, environmental and singular determinants.

\section{REFERENCES}

1. Garcia M, Miller VM, Gulati M, Hayes SN, Manson JE, Nanette $\mathrm{KW}$, et al. Focused cardiovascular care for women: the need and role in clinical practice. Mayo Clin Proc [Internet]. 2016 feb; [cited 2019 jan 12]; 91(2):226-40. Available from: https://doi.org/10.1016/j. mayocp.2015.11.001

2. Knaul FM, Langer A, Atun R, Rodin D, Frenk J, Bonita R. Rethinking maternal health. Lancet Glob Health [Internet]. 2016 mar; [cited 2016 dec 20]; 4(4):PE227-E228. Available from: https://doi.org/10.1016/ S2214-109X(16)00044-9

3. Campanharo FF, Cecatti JG, Haddad SM, Parpinelli MA, Born D, Costa $\mathrm{ML}$, et al. The impact of cardiac diseases during pregnancy on severe maternal morbidity and mortality in Brazil. PLoS One [Internet]. 2015 dec; [cited 2016 dec 20]; 10(12):e0144385. Available from: https://doi. org/10.1371/journal.pone.0144385

4. Martins LC, Freire CMV, Capuruçu CAB, Nunes MCP, Rezende CAL. Risk prediction of cardiovascular complications in pregnant women with heart disease. Arq Bras Cardiol [Internet]. 2016 apr; [cited 2016 dec 20]; 106(4):289-96. Available from: http://dx.doi.org/10.5935/abc.20160028

5. Simpson LL. Preconception considerations. Semin Perinatol [Internet]. 2014; [cited 2019 feb 01]; 38(5):236-9. Available from: https://doi. org/10.1053/j.semperi.2014.04.011

6. Ministério da Saúde (BR). Instituto Sírio-Libanês de Ensino e Pesquisa. Protocolos da Atenção Básica: Saúde das Mulheres. Brasilia(DF):Ministério da Saúde; 2016; [cited 2019 mar 01]. Available from: http://bvsms.saude. gov.br/bvs/publicacoes/protocolos_atencao_basica_saude_mulheres.pdf

7. Ministério da Saúde (BR). Secretaria de Atenção à Saúde. Departamento de Ações Programáticas Estratégicas. Gestação de alto risco: manual técnico. Brasília (DF): Ministério da Saúde; 2012; [cited 2019 mar 01]. Available from: http://bvsms.saude.gov.br/bvs/ publicacoes/manual_tecnico_gestacao_alto_risco.pdf

8. Liu F, Parmerter J, Straughn M. Reproductive Life Planning: A concept analysis. Nurs Forum [Internet]. 2016 jan; [cited 2019 feb 01]; 51(1):5561. Available from: $\mathrm{https}: / /$ doi.org/10.1111/nuf.12122

9. Ministério da Saúde (BR). Secretaria de Atenção à Saúde. Departamento de Atenção Básica. Caderno de Atenção Básica: Saúde Sexual e Reprodutiva. Brasília (DF): Ministério da Saúde; 2013.

10. Hebson C, Saraf A, Book WM. Risk assessment and management of the mother with cardiovascular disease. Clin Perinatol [Internet] 2016 mar [cited 2019 feb 03]; 43(1):1-22. Available from: https://doi. org/10.1016/j.clp.2015.11.001

11. Amorim TV, Souza IEO, Salimena AMO, Melo MCSC, Paiva ACPC, Moura MAV. The everyday of a heart disease high-risk pregnancy: phenomenological study of care relationships. Esc Anna Nery [Internet]. 2016; [cited 2019 aug 14]; 20(4):e20160091. Available from: http://www.scielo.br/scielo.php?script=sci_arttext\&pid=S141481452016000400209\&Ing=en\&nrm=iso\&tIng=en

12. Heidegger M. Ser e Tempo. Tradução de Márcia Sá Cavalcanti Schuback. Petrópolis (RJ): Vozes; 2011.

13. Amorim TV, Souza IEO, Salimena AMO, Queiroz ABA, Moura MAP, Melo MCSC. Reproductive risk in pregnant women with heart diseases: The living world guiding health care. Texto Contexto - Enferm [Internet] 2018; [cited 2019 sep 11];27(2):e3860016. Available from: http://dx.doi. org/10.1590/0104-070720180003860016

14. Minayo MCS. Amostragem e saturação em pesquisa qualitative consensus e controvérsias. Rev Pesq Qual [Internet]. 2017 apr; [cited 2019 mar 14]; 5(7):1-12. Available from: https://edisciplinas.usp.br/ pluginfile.php/4111455/mod_resource/content/1/Minayosaturacao.pdf

15. Fontanella BJB, Ricas J, Turato ER. Amostragem por saturação em pesquisas qualitativas em saúde: contribuições teóricas. Cad Saúde Pública [Internet]. 2008 jan; [cited 2019 aug 23]; 24(1):17-27. Available from: http://dx.doi.org/10.1590/S0102-311X2008000100003 
16. Oliveira DC, Mandú ENT.Women with high-risk pregnancy: experiences and perceptions of needs and care. Esc Anna Nery [Internet]. 2015 mar; [cited 2016 dec 20]; 19(1):93-101. Available from: http://www.scielo.br/ pdf/ean/v19n1/en_1414-8145-ean-19-01-0093.pdf

17. Luiz MS, Nakano AR, Bonan C. Planejamento reprodutivo na clínica da família de um Teias: condições facilitadoras e limites à assistência. Saúde Debate [Internet]. 2015 set; [cited 2019 aug 15]; 39(106):671-82. Available from: http://dx.doi.org/10.1590/0103-110420151060003009

18. Xavier RB, Bonan C, Martins AC, Silva KS. Reproductive risks and comprehensive care of pregnant women with hypertensive syndromes: a transversal study. Online Braz J Nurs [Internet]. 2013 dec; [cited 2016 nov 12]; 12(4):823-33. Available from: http://www.objnursing.uff.br/index. php/nursing/article/view/4249/pdf_28

19. Viellas EF, Domingues RMSM, Dias MAB, Gama SGN, Theme Filha MM, Costa JV, et al. Assistência pré-natal no Brasil. Cad Saúde Pública [Internet]. 2014; [cited 2019 aug 15]; 30(Suppl 1):S85-S100. Available from: http://dx.doi.org/10.1590/0102-311X00126013

20. Xavier RB, Bonan C, Silva KS, Nakano AR. Itinerários de cuidados à saúde de mulheres com história de síndromes hipertensivas na gestação. Interface (Botucatu) [Internet]. 2015 dec; [cited 2019 aug 15]; 19(55):1109-20. Available from: http://dx.doi.org/10.1590/180757622014.0112
21. Tedoldi CL, Freire CMV, Bub TF. Sociedade Brasileira de Cardiologia. Diretriz da Sociedade Brasileira de Cardiologia para Gravidez na Mulhe Portadora de Cardiopatia. Arq Bras Cardiol [Internet]. 2009; [cited 2016 nov 12]; 93(6 Suppl 1):e110-e178. Available from: http://publicacoes. cardiol.br/consenso/2009/diretriz_card_grav_9306supl1.pdf

22. Andrade RD, Santos JS, Maia MAC, Mello DF. Factors related to womens health in puerperium and repercussions on child health. Esc Anna Nery [Internet]. 2015 mar; [cited 2016 oct 2]; 19(1):181-6. Available from http://www.scielo.br/pdf/ean/v19n1/en_1414-8145-ean-19-01-0181.pd

23. Pierre LAS, Clapis MJ. Planejamento familiar em Unidade de Saúde da Família. Rev Latino-Am Enfermagem [Internet]. 2010 nov/dec; [cited 2016 may 30]; 18(6):[aprox.8 telas]. Available from: http://www.scielo. $\mathrm{br} / \mathrm{pdf} / \mathrm{rlae} / \mathrm{v} 18 \mathrm{n} 6 / \mathrm{pt} \_17 . \mathrm{pdf}$

24. Sauthier M, Gomes MLB. Gênero e planejamento familiar: uma abordagem ética sobre o compromisso profissional para a integração do homem. Rev Bras Enferm [Internet]. 2011 may/jun; [cited 2016 may 30]; 64(3):457-64. Available from: http://www.scielo.br/pdf/reben/v64n3/ v64n3a08.pdf

25. Clapp MA, Bernstein SN. Preconception counseling for women with cardiac disease. Curr Treat Options Cardiovasc Med [Internet]. $2017 \mathrm{sep}$ [cited 2019 mar 01]; 19(6):67. Available from: https://doi.org/10.1007/ s11936-017-0565-Z 